\title{
Standard contracts in bank credit agreements
}

\author{
Montayana Meher* and Ningrum Natasya Sirait \\ Doctoral Progam in Law, Graduate School, Universitas Sumatera Utara, Medan, Indonesia
}

\begin{abstract}
The application of standard contracts in bank credit agreements have triggered many legal issues in questions. In banking practice, each bank provides a form of credit agreement that has been prepared in advance. The type of agreements known as standard agreements. Using standard agreement is often problematic. Problems encountered in the standard agreements are the validity of the standard agreements and the making of clauses or provisions which are unreasonably burdensome to the parties, especially the debtor, which is called the exoneration clause. The existing credit agreements in Indonesian banking system are so diverse, means there is no uniformity. Each bank produce or prepare its own rules with certain clauses that may impair the customers. There is a need for a legislation that regulates credit matters and it is expected that it contains rights and obligations of the parties in preparing the agreement.
\end{abstract}

\section{Introduction}

Agreement is prepared based on the principle of freedom of contract between parties where parties seek to reach necessary consensus through a process of negotiation between them. These days there is an increasing tendency that many contracts in business transactions existed not through a sensible negotiation process between the parties. However, the agreement existed because one party has prepared the standard terms or clause on printed form and presented to the other party for approval with literally no opportunity to negotiate on the terms. Such contracts are define as standard contracts.[1]

Freedom of contract is based on an assumption that parties to the contract have an equivalent bargaining position. In reality, the parties do not always have equal bargaining position. As a consequences, party with stronger bargaining position tends to control the other party with weaker bargaining position.[2] Party with weaker bargaining position will accept the contents of the contract under pressure. If the person tries to propose bargain alternative or option of the content in the contract, the person is likely to lose what he/she needs obtain from the agreement. Therefore, there are only two options for the party with weaker bargaining position, either to accept or to refuse the offer (take it or leave it). [3]

In accordance with the main principle of an agreement, namely the principle of freedom of contract as implied in Article 1338 of the Civil Code, the parties that bind themselves in a credit agreement can refer either to the provisions existing in the Civil Code or to the mutual agreement. This means that in the case of mandatory provisions, the agreement must

*Corresponding author: montayanameher@yahoo.com 
accord with the provisions of the Civil Code, whereas in the case of non-compulsory provisions, it is entirely left to the parties' mutual consent. [4]

The law recognizes a person's autonomous right to freely make an agreement with any person and determines the content of the agreement. In addition to the principle of freedom of contract, the principle of binding force states that all legally-made agreements shall apply as laws to those who prepared them, as set forth in the provisions of Article 1338 of the Civil Code.

The other fundamental principle of contract law is the principle of a consensus. In addition to the above principles, there is also a principle of equilibrium stating that the principles of contract law in particular or the legal instruments contained in the Civil Code shall be established based on the legal values and norms. [5]

The phenomenon of imbalance position in contracts as stated earlier can be observed from a number of contract models, especially standard contracts with unfair clauses. For example such as credit provision in banking sector, where we may find clause on responsibility transfer of business actors and or consumer's compliance to new, additional, new or subsequent regulations, and/or further changes made unilaterally by the business actors.

In banking practices, each bank provides a form of credit agreement that has been prepared in advance. This credit agreement form shall be submitted to the debtor for approval without giving any opportunity to the other party to negotiate on the terms provided. [6] The use of standard agreements is problematic. The problems encountered in the standard agreement are the validity and the making of clauses or provisions which are unreasonably burdensome to the other party, especially the debtor.

The exoneration clause usually contained in the agreement as an additional clause is usually disadvantageous for the consumer who generally has weaker position compared to the producer. The existence of such clause place a burden to the consumer. The application of certain clauses by a party with a stronger position which is harmful is usually known as the misuse of the condition (misbruik van omstadigheden). [7]

\section{Problem}

The problem question in this study is why are the validity of the standard agreement and the making of its clauses or provisions unreasonably burdensome to the other party, especially the debtor?

\section{Research methods}

This research is normative legal study. The data used was in this paper obtain from secondary data consisting of (a) primary legal materials in the form of legislation, (b) secondary law materials in the form of writings, both books and articles containing comment or analysis related to the subject matter, and (c) tertiary legal materials in the form of dictionaries. The data collected using a literature review and document analysis and using qualitative method.

\section{Discussion}

\subsection{Legal relationship between the bank and its customers}

As a financial institution, banks play a strategic role in the life of a state's economy. The institution is intended as an intermediary body between parties with surplus of funds and 
parties with lack of funds. Banks will engage in as credits provider in various services to its customers. Banks serve financial assistance as well as smoothening the payment system mechanism for all economic sectors. [8]

The word credit comes from "credere" which means trust. This means that the creditor give their trust to the debtor that the credit provided will certainly be repaid in accordance with the agreement. As for the recipient of the credit, this means accepting the trust, so the borrower has an obligation to repay the loan in accordance with the time period. Therefore, to make sure that the customer is truly trustworthy, the bank usually conducts credit analysis before the credit is given. Credit analysis includes the background of the customer or the company, its business prospects, the collateral provided and other factors. The purpose of the analysis is for the bank to be confident that the credit provided is completely secure. [9] According to Law Number 10 of 1998 on Banking Service, credit is the provision of money or equivalent claims, based on a loan agreement between the bank and another party requiring the borrower to repay the debt after a certain period of time with added interest.

Any credit approved and agreed between the creditor and the debtor must be set forth in a written credit agreement. This credit agreement should be carefully considered by both, the bank as a creditor and the customer as a debtor. The credit agreement has very important function in the provision, management and administration of the credit.

The relationships between the bank and its customers can be categorized as the relationship between a creditor and a debtor, trust relation (fiduciary relation) and confidential relation. The relationship between bank and customer are accompanied by prudential relation principle. These four relationships underpin the relationship between the bank and its customers.

Symons $\mathrm{Jr}$ argued that the relationship between bank and customer is a debtor-creditor relationship which suggests a determination of obligations in a narrow sense. The term refers to an unconditional assurance by the debtor to pay a certain amount of money at a certain time to the creditor that has provided the money. It further indicates that the debtor has no other obligations, unless otherwise specified, especially with regard to the use of the borrowed money. In a bank deposit for example, the bank may use the money freely at will. However, the relationship between a bank and a customer is not solely a debtor-creditor relationship, it also serves as a fiduciary relation. [10]

\subsection{Validity of the standard agreement}

In the contract law, there are three principles which are interrelated to each other, namely the principle of consensus, the principle of freedom of contract, and the principle of binding force. The principle of consensus was born at the initial moment of the agreement, namely at the time when the parties reach a mutual agreement. The parties enter the stage of freedom of contract when determine the rights and obligations as well as other matters related to the substance of the agreement, Under this principle, the parties can determine the form and content freely as long as they can be held accountable. Reciprocal approval of the form and content of the agreement becomes the recognition of a valid will to the content of the agreement. As a result, the agreement is binding for both parties and should be performed in a good faith. [11]

Under the principle of freedom of contract, an individual possess the right to have the freedom to sign a contract, to determine the content of the contract, to determine the form of the contract, and to choose the law applicable to the contract concerned. If the principle of consensus relates to the commencement of a contract, the principle of binding force relates to the legal consequences and the principle of freedom of contract relates to the content of the contract. 
Freedom of contract is one of the most important principles in the agreement. Freedom of contract is the byword of free will and substantiate human rights. This freedom of contract is a base in the ideology of individualism found in Greek era, continued by the Epicurists and thrived in the Renaissance Age. The principle among others, convey through famous intellectual such as Hugo de Groot, Thomas Hobbes, John Locke and Rosseau. The uttermost of its development achieved after the French revolution.

In the nineteenth century, as the economic doctrine of laissez faire prevailed, freedom of contract became a general principle in favor of the free competition. Freedom of contract became the embodiment of the principle of free trade law. Any state intervention to the contract is against the principle of the free trade. Freedom of contract has become a new paradigm in the contract law that is highly exalted by philosophers, lawyers and courts.[10]

Freedom of contract may only achieve fairness if the parties have equal bargaining power. If the bargaining power is unequal, then a contract tends to be or become unconscionable. In addition, although the principle of equilibrium and conformity of the parties' position exists, the implementation often results in an imbalanced and unsuitable contract (inappropriate and unfair).

A credit agreement is a standard contract in which the content or clauses of the credit agreement has been standardized and set forth in a written form but not bound in a particular form (vorn vrij). A prospective debtor signs only if he/she is willing to accept the content of the agreement. The bank does not give an opportunity to a prospective debtor to discuss further details about the content or clauses proposed by the bank. In this agreement, the position of the prospective debtor is weak, so he/she can only accept all the conditions proposed by the bank, otherwise, the prospective debtor will not get the requested credit.[11]

Principally, the parties to a contract are free to self-govern the contract in accordance with the principle of freedom of contract, as defined in Article 1338 Paragraph (1) of the Civil Code. Article 1338 Paragraph (1) specifies that all legally- agreed contracts pertain as laws to those who bound them.

In an agreement where the terms, conditions or contents set forth in the clauses have been standardized, the legal position of one party is more dominant than the other party's. This has made a party to be restricted or constrained in expressing his/her will because he/she being offered an agreement with predetermined terms. In standard agreement, the rights of one party are more prominent than other's and this has consequences to the rights and obligations between the parties to be imbalanced.

Jurists such as Sluijter and Pitlo, disagree the existence of the standard agreement. Sluijter argues that this standard agreement is not accepted as an agreement, because the entrepreneur's position in the agreement is similar to private law maker (legio particuliere wetgever). The conditions specified by the entrepreneur in the agreement are laws and not considered as agreement. While Pitlo maintains that the background to the growth of the standard agreement is the social and economic need, large corporations, semi-governmental enterprises or government enterprises entering into cooperation for their interests in determining certain conditions unilaterally. By using this standard agreement, the entrepreneur will obtain the efficient use of cost, labor and time which describes a picture of a pragmatic society. [12]

However, there are also jurists who are proponent to this standard agreement. Stein argues that a standard agreement can be accepted as an agreement based on the willingness and trust that parties are bound to the agreement. If the debtor accepts an agreement, it means he or she freely and voluntarily agrees on the content of the agreement.

Asser-Rutten argues that everyone who signs an agreement is responsible for the content that he/she has agree and signed a. If somebody signs a standard agreement form, the signature raises the expectation that the undersigned knows and wants the content of the 
signed form. It is impossible for a person to sign what he/she does not know nor understand. [13]

Another jurist, Hondius insists that the standard agreement has binding power based on customs prevailing in the community and trade transactions. While an Indonesian jurist, Mariam Darus argues that although theoretically a standard agreement does not meet the provisions of the law and is rejected by some jurists, but in reality, the needs of the society require the existence of this standard agreement. [14]

\subsection{The exoneration clause in a credit agreement}

The phenomenon of imbalance in a contract as mentioned above can be observed from a number of contract models, especially standard contracts with clauses of biased content. In the practice of credit provisions in the banking sector, for example, there is a clause that obliges the customer to comply with any bank guidance and regulation, either existing or to be regulated later, or a clause that exempts the bank from customer's loss as a result of the bank action. [15]

The standard agreement brings about negative impact in the sense that a party with a strong bargaining position can impose his/her will on the weak, and the strong benefits from the action. In the development of various jurisdictions, the state intervenes to protect the weak party either through judicial decisions or by issuing regulations made by the legislature. In that connection, some basic rules that must be observed for an unsigned written agreement and contain the standard terms such as the principle of duty to read prevailing in the United States prior to the 1960s for signed documents, the principle of public policy and the principle of unconscionability.

In 1854, the British parliament introduced a law that attempted to limit the freedom of the seller to make clauses in a standard contract to protect the purchaser of goods/services, beginning with the law on the channel and train transport. In the nineteenth century, other laws pertaining to certain contracts were also enacted in England as in other industrialized countries. For example, in 1893 the Sale of Goods Act was enacted. Later in the United States, similar provisions, namely the Uniform Sales Act, in 1906, were accepted by the National of Commissioners on Uniform State Laws. [16]

Therefore, the arrangement of the content of an agreement is not solely left to the parties, but it should be monitored by government institution especially against the standard agreement. [17] The government as the bearer of the public interests should keep the balance of individual and public interests. Allowing the making of an agreement to be in the sole mechanism of freedom of contract would create the imbalance and unconformity of the contracting parties. Therefore, the principle of freedom of contract requires restrictions on its operation by determining prohibited or required clauses in the form of laws.

\section{Conclusions}

\subsection{Summary}

Despite the existence of standard credit agreements which poses some problems in terms of the construction of clauses, especially the exoneration clause that incriminates the debtor, such agreements are still needed. Therefore, the arrangement of the content of an agreement is not solely left to the parties, but it should be monitored especially against the standard agreement. The government as the bearer of the public interests should keep the balance of individual and public interests. 


\subsection{Recommendation}

The existing credit agreements in the banking system in Indonesia are so diverse that there is no uniformity. Every bank creates its own rules with certain clauses that may harm customers. Therefore, there is a need for legislation to regulate the credit agreement in terms of the rights and obligations of the parties.

\section{References}

1. S.R. Sjahdeni, Kebebasan berkontrak dan perlindungan yang seimbang dalam perjanjian kredit bank di Indonesia, (Institut Bankir Indonesia, Jakarta, 1993).

2. R. Khairandy, Itikad baik dalam kebebasan berkontrak, (Fakultas Hukum UI, Jakarta, 2004).

3. Shidarta, Hukum Perlindungan Konsumen Indonesia, (Grasindo, Jakarta, 2004).

4. M. D. Badrulzaman, K.U.H. Perdata Buku III tentang Hukum Perikatan dan Penjelasannya, (Alumni, Bandung, 2005).

5. H. Budiono, Kumpulan tulisan hukum perdata di bidang kenotariatan, (Citra Aditya Bakti, Bandung, 2008).

6. J. Ibrahim, Bank sebagai lembaga intermediasi dalam hukum positif, (CV. Utomo, Bandung, 2004).

A. Miru \& S. Yodo, Hukum perlindungan konsumen, (Raja Grafindo Persada, Jakarta, 2004).

7. M. Djumhana, Hukum perbankan di Indonesia, (Citra Aditya Bakti, Bandung, 2003).

8. Kasmir, Dasar-dasar perbankan, (Raja Grafindo Persada, Jakarta, 2000).

9. R.S.H. Bako, Hubungan bank dan nasabah terhadap produk tabungan dan deposito (Suatu tinjauan hukum terhadap perlindungan deposan di Indonesia dewasa ini), (Citra Aditya Bakti, Bandung, 1995).

10. T. Kamello, Karakter hukum perdata dalam fungsi perbankan melalui hubungan antara bank dengan nasabah, Pidato Pengukuhan Jabatan Guru Besar Tetap dalam Bidang Ilmu Hukum Perdata, (Fakultas Hukum Universitas Sumatera Utara, Medan, 2006).

11. C. Elliot, and F. Quinn, Contract law, Fourth Edition, (Pearson Education, England, 2003).

12. R. Usman, Aspek-aspek hukum perbankan di Indonesia, (PT Gramedia Pustaka Utama, Jakarta, 2001).

13. Sluijter, De standaardcontracten, de grenzen van de particuliere wetgever, (KluwerDeventer, 1972).

14. Asser-Ruttem, Handleiding tot de beofening van het Nederland burgerlijk, (W.E.J. Tjeenk-Willink Zwole, 1968).

15. M.D. Badrulzaman, Aneka hukum bisnis, (Alumni, Bandung, 2005).

16. A.Y. Hernoko, Hukum perjanjian: Azas proporsionalitas dalam kontrak komersial, (LaksBang Mediatama Yogyakarta Bekerjasama dengan Kantor Advokat "Hufron \& Hans Simaela", Yogyakarta, 2008).

17. M. Fuady, Perbandingan hukum perdata, (Citra Aditya Bakti, Bandung, 2005). 